PAEDAGOGIA CHRISTIANA

I/21 (2008) - ISSN 1505-6872

Remigiusz Lota*

Częstochowa

\title{
Pedagogia Ruchu Światło-Życie propozycją „na dzisiejszą godzinę Kościoła”
}

Ponad trzydzieści lat temu, ks. Franciszek Blachnicki stawiał w Kościele pytanie o katechumenat „na dzisiejszą godzinę”, który umożliwiłby w sposób owocny realizowanie procesu stawania się chrześcijaninem i dochodzenia do dojrzałej wiary w ramach każdej wspólnoty lokalnej Kościoła i parafii. Wtedy, według Sługi Bożego, był to najbardziej aktualny problem polskiego Kościoła ${ }^{1}$. Warto się zastanowić, czy jednak nie pozostaje on nadal naszym najbardziej aktualnym problemem? I czy w tym kontekście nie warto na nowo popatrzeć na pedagogię Ruchu Światło-Życie i jego zadania w ramach dzieła odnowy Kościoła? Celem tego Ruchu jest być jednym z elementów, czy jedną z prób odnowy katechumenatu w ramach naszych wspólnot lokalnych. Animatorzy i inni odpowiedzialni zdobywają coraz większą świadomość sensu i celu swojej pracy w grupach, wspólnotach oazowych, które chcą być wspólnotami formacyjnymi typu katechumenalnego w parafiach. Ruch Światło-Życie przez czas swojego istnienia okrzepł, zmienił się, dojrzał w świadomości swoich członków, przestał być przejawem spontanicznej aktywności młodzieży, a stał się bardziej jedną z form duszpasterstwa. Stało się to, co przewidywał ks. F. Blachnicki, iż „minie moda na oazy". Wydaje się jednak, że w swojej formule Ruch Światło-Życie nie stracił na aktualności. Nie jest prawdą, że jego założenia były dobre tylko na czasy minione. Wspólnoty oazowe wciąż mają moc przyciągającą i ożywiającą Kościół, i wydaje się, że to ciągle „drzemiący olbrzym”, którego potencjał nie jest wykorzystany ani w Kościele, ani w świecie ${ }^{2}$.

${ }^{*}$ Ks. dr Remigiusz Lota, wykładowca homiletyki i katechetyki w Wyższym Seminarium Duchownym w Częstochowie, ojciec duchowny alumnów, moderator wspólnoty Boga Ojca.

${ }^{1}$ Biblioteczka animatora, z. 2: Katechumenat Wspólnoty formacyjne we wspólnocie lokalnej, Światło-Życie, Krościenko 2002, s. 3.

${ }^{2}$ Por. Z. Nosowski, Oazy, drzemiacy olbrzym, Więź 32 (1989), nr 4, s. 31-47. 
Niewykorzystanie owego potencjału, tkwiącego szczególnie w głębokiej formacji chrześcijańskiej członków Ruchu Światło-Życie, wynikało m.in. z trudności, na jakie napotykały w swojej działalności wspólnoty oazowe, z niezrozumienia ze strony ich duszpasterzy, albo z tkwiącej ciaggle jeszcze w wielu katolikach mentalności przedsoborowej, która całą odpowiedzialność za Kościół pozostawiała duszpasterzom, nie rozumiejąc do końca i „obawiając się” nowej, soborowej koncepcji parafii, czyniącej z wszystkich jej członków podmiot wszelkich działań duszpasterskich. Wydaje się jednak, że ów niewykorzystany potencjał, tkwiący w systemie formacyjnym Ruchu Światło-Życie, ma swoje przyczyny również w sposobie realizowania założeń formacyjnych ks. F. Blachnickiego, a także trudności w odczytywaniu ,na dzisiejszą godzinę” jego intuicji pastoralnych przez jego następców.

Działanie ks. F. Blachnickiego było ustawicznym odczytywaniem znaków czasu. Umiał on je wspaniale odczytywać, odpowiednio przekładać sformułowane na język praktyki i wcielać w życie. Bycie „na bieżąco” ks. F. Blachnickiego sprawiało, że wczytując się w dokumenty Soboru Watykańskiego, a jednocześnie śledząc historię i wydarzenia jemu współczesne, „na bieżąco” również tworzył nowe formy duszpasterskie, które natychmiast wcielał w program wspólnot oazowych, a przez nie w życie parafii. Tak było z Krucjata Wstrzemięźliwości, Krucjata Wyzwolenia Człowieka, czy z programem wielkiej ewangelizacji $\mathrm{Ad}$ Christum Redemptorem. Jako ,wizjoner” i prorok, w swoich intuicjach pastoralnych wyprzedzał czasy. Do dziś kluczową sprawą dla Ruchu Światło-Życie jest konieczność aktualizującego odczytywania owych intuicji ks. F. Blachnickiego. Ruch Światło-Życie stanął po śmierci swego założyciela wobec nowych wyzwań. Odczytując myśli pastoralne Sługi Bożego, szuka w nich odpowiedzi na pytanie, co byłoby dziś, jego zdaniem, najważniejsze. Zasadniczym pytaniem dla Ruchu Światło-Życie wobec tak wielkich wyzwań współczesności, staje się pytanie, czy formacja w Ruchu przystosowana jest do nowych potrzeb? I czy wierność ks. F. Blachnickiemu w dzisiejszej rzeczywistości ma polegać na „na ciagłym powtarzaniu jego wskazówek i powielaniu starych materiałów formacyjnych, niezależnie od zmieniającej się rzeczywistości, czy też na takim przetwarzaniu ich pod względem metody, formy, języka, by lepiej odpowiadały potrzebom i wyzwaniom nowych czasów?"3.

Nowa sytuacja społeczno-kulturowa współczesności stała się szczególnym wyzwaniem dla Kościoła. Jego odpowiedzią na zmieniającą się sytuację świata,

${ }^{3}$ Z. Nosowski, Oto czynię wszystko nowe...Kościót wobec wyzwań wspótczesności, w: Deuterokatechumenat. Referaty. Dyskusja panelowa. Stowo programowe. Homilie. XXVII Kongregacja Odpowiedzialnych Ruchu Światto-Życie, Częstochowa-Jasna Góra 1-4 marca 2002 r., Katowice 2002, s. 63. 
w którym przyszło mu pełnić posługę zbawienia i na sytuację człowieka, ku któremu bezpośrednio kieruje się jego misja, był - widoczny szczególnie w dokumentach Soboru Watykańskiego II - powrót do Pisma Świętego i odnajdywanie w nim podstaw chrześcijańskiego ideału wychowawczego. Kerygmatyczne ujmowanie nauczania i wychowania religijnego było przede wszystkim poszukiwaniem w biblijnej myśli wychowawczej takiego sposobu wychowania człowieka w rodzinie, w społeczeństwie, w Kościele, które odnawiałoby postawę osobistej wiary, budziło postawę dialogu i odpowiedzi na Boże wezwanie. Ów kerygmatyczny i eklezjocentryczny charakter edukacji religijnej cechuje pedagogię oazową, stworzona przez ks. F. Blachnickiego, jednego z czołowych przedstawicieli polskiej katechezy epoki odnowy materialno-kerygmatycznej.

Koncepcja wychowawcza Ruchu Światło-Życie, zanurzona głęboko w kerygmatycznym nurcie nauczania i wychowania religijnego, oparta na silnych podstawach nadprzyrodzonych, przeniknięta rzeczywistością Słowa Bożego i liturgii ${ }^{4}$, wywarła i wywiera nadal pozytywne skutki w formacji religijnej chrześcijan, w ich rozwoju wiary personalnej i wspólnotowej. Postulat katechumenatu rodzinnego i parafialnego, konieczność przeżycia wspólnoty chrześcijańskiej, a z tym związana potrzeba włączenia katechezy w całe życie Kościoła - to niewątpliwie zalety koncepcji nauczania i wychowania religijnego Ruchu Światło-Życie. Edukacja religijna w tej koncepcji polega na przepowiadaniu Chrystusa w Kościele, i dążeniu do tworzenia wspólnoty (koinonii), poprzez którą - przez świadectwo wiary, nadziei i miłości - mogą dokonywać się wewnętrzne przemiany w świecie 5 .

Koniec lat sześćdziesiątych i lata siedemdziesiąte $\mathrm{XX}$ wieku pokazały jednak niewystarczalność kerygmatycznego ujęcia nauczania i wychowania religijnego. Procesy sekularyzacyjne i dechrystianizacyjne miały wielki wpływ na życie Kościoła, na treść i metodę wychowawczego oddziaływania, a także na nauczanie religii. Coraz częściej zaczęto uważać, iż wskutek jednostronności katechezy egzegetycznej, koncentrującej się na analizie tekstów biblijnych, nauczanie religijne odeszło od realiów życia wychowanków ${ }^{6}$. Stąd dający się zauważyć postępujący w nim proces przechodzenia od tematyki biblijnej do tematyki współczesnej, dla której teksty biblijne zaczynają odgrywać rolę służebną. Procesy przemian społecznych i kulturowych tego czasu spowodowały duży rozdział między wiarą i jej praktyką, a tym samym między językiem katechetycznego przekazu a mentalnością odbiorców. Niewystarczające okazywało się już samo ujmowanie treści nauczania w kategoriach Dobrej Nowiny, wzbudzanie postawy dialogu i odpowiedzi na Boże wezwanie?

${ }^{4}$ Por. M. Majewski, Koncepcja katechezy w ujęciu ks. dra hab. Franciszka Blachnickiego, w: Gorliwy apostoł wewnętrznej odnowy człowieka. Materiaty z sympozjum poświęconego założycielowi Ruchu Światto-Życie. Lublin 5-6 października 1987 r., Lublin 1988, s. 27.

${ }^{5}$ Por. Tamże, s. 30.

${ }^{6}$ J. Kudasiewicz, Wymiar biblijny, w: Podstawowe wymiary katechezy, red. M. Majewski, Kraków 1991, s. 30-31.

${ }^{7}$ Por. J. Charytański, Kryzysy religijne katolickiej młodzieży, Katecheta 8 (1964), s. 52-57. 
Nastawienie na przekazywanie kerygmatu w katechezie sprawiło, iż problemy ludzkie w dużej mierze znalazły się na uboczu. Katecheza zaś zamiast być wprowadzeniem w życie przez wspólnotę Kościoła, zaczęła tworzyć ekskluzywne grupy wewnątrz Kościoła, które, świadome konieczności świadectwa, nie były zdolne nawiązać kontaktu z konkretnym życiem ${ }^{8}$. Stąd, pojawił się w nauczaniu i wychowaniu religijnym kierunek antropologiczny, który, akcentując potrzebę nawiązania do problemów, którymi żyje młode pokolenie, oraz zmianę języka, który byłby bliższy mentalności pokolenia dorastającego w świecie pluralistycznym, podstawą treści katechetycznego przekazu czyni problemy egzystencjalne człowieka ${ }^{9}$.

Owocem takiego zorientowania w katechezie było dostrzeżenie problemu coraz mocniejszego wpływu czynników środowiskowych na proces wychowania religijnego, pod których wpływem kształtuje się typ człowieka o nowej mentalności ${ }^{10}$. Prowadziło to do postawienia wniosku, iż aby nauczanie i wychowanie do dojrzałości wiary mogło być skuteczne, należy poznać mentalność współczesnego człowieka, a następnie uszanować te wartości, którymi on żyje. Bowiem tylko w ten sposób można ukazać mu możliwość realizacji tych wartości na płaszczyźnie współdziałania człowieka z Bogiem.

Należy tu również powiedzieć o znaczącym wpływie na wychowanie chrześcijańskie mentalności samego wychowawcy, która winna być mentalnością ewangeliczną, umiejącą zachować równowagę między wartościami boskimi i ludzkimi w przekazie katechetycznym. Równowagę tę określa się często jako

${ }^{8}$ Por. M. Majewski, Tożsamość katechezy integralnej, Kraków 1995, s. 112.

${ }^{9}$ Por. tenże, Antropologiczna koncepcja katechezy, Kraków 1995, s. 171-190.

${ }^{10}$ Podczas dorocznych spotkań francuskich katechetów, tzw. Paryskich Dni Katechetycznych w 1962 r., wskazano na cztery specyficzne cechy mentalności współczesnego człowieka, ważne szczególnie w nauczaniu i wychowaniu religijnym młodzieży. Najpierw jest to poczucie potrzeby bezpieczeństwa. Młody człowiek, pragnąc być pewnym stałości tego wszystkiego, co wytycza jego czynności na co dzień, oczekuje, iż ci, którzy uczestniczą w jego wychowaniu (także w wychowaniu religijnym), będą liczyli się $\mathrm{z}$ jego nastawieniem, z jego ocenami czy pojęciami moralnymi, może zachwiać tym poczuciem. Druga cecha mentalności to potrzeba radości i poczucia rozwo$j u$. Człowiek współczesny, świadomie pragnąc zaspokojenia swoich przyjemności, korzystania ze wszystkich wygód i radości, które daje mu współczesna cywilizacja, odwraca się od wszelkiego wyrzeczenia się. Wychowanie religijne, stawiające wymagania, domagające się nierzadko wyrzeczenia się dóbr materialnych dla wartości duchowych, może stawać się dla niego w tym momencie zagrożeniem i małą szansą na zrealizowanie swoich życiowych pragnień. Trzecia cecha mentalności to potrzeba uznania ze strony grupy. Osoba odtrącona w jakikolwiek sposób przez grupę przeżywa zachwianie poczucia bezpieczeństwa, budzi w nim lęk i niepewność. Stąd człowiek liczy na uznanie grupy i z natury pragnie go. Czwarta cecha tej mentalności to wysuwanie na pierwsze miejsce tego, co ludzkie, człowiecze. Dlatego tyle dziś mówi się o prawach człowieka. Sam człowiek postrzega siebie jako naczelny cel, a nawet źródło prawa. Rości sobie prawo do wolności, życia, pracy, zdrowia, wykształcenia, radości. Religię może nierzadko postrzegać jako stojącą w opozycji do wielu tych pragnień (por. J. Bagrowicz, Edukacja religijna współczesnej młodzieży. Źródła i cele, Torun 2000, s. 262. 
wierność Bogu i człowiekowi ${ }^{11}$. Ten tzw. integralny model katechezy ${ }^{12}$ ma na celu takie przekazywanie orędzia (nie wiedzy czy doktryny), które będąc z natury swej Boże, pozostaje w bezpośredniej relacji do człowieka, rozwiązuje jego problemy egzystencjalne, wprowadza sens życia i służy jego przemianie ${ }^{13}$. Według tego modelu, właściwym sposobem nauczania i wychowania religijnego wydaje się więc taki, który byłby otwarty na zwykłe sprawy ludzkie, dobro człowieka, a nie zamykał się jedynie w kręgu spraw dotyczących życia wiecznego ${ }^{14}$.

Te wszystkie nowe wyzwania stanęły również przed pedagogią Ruchu Światło-Życie, której koncepcja, zakorzeniona głęboko w kerygmatycznym nurcie nauczania i wychowania chrześcijańskiego, musiała zmierzyć się z nadchodzącą falą przemian społecznych i kulturowych w Polsce.

Ruchowi Światło-Życie zarzucano (często słusznie), iż mimo tego, że jego Założyciel był człowiekiem niesłychanie wrażliwym społecznie, przekonanym i konsekwentnym przeciwnikiem komunizmu, teologiem wyzwolenia, to ruch, który stworzył, często jakby nie zauważał narastających problemów społecznych, skupiając się nade wszystko na wąsko rozumianej formacji religijnej. Zniechęcenie społeczne, jakie obserwuje się we współczesnym społeczeństwie polskim, brak zaufania do polityki (a przede wszystkim polityków), rozczarowanie demokracją, odzywająca się w wielu tęsknota za pozorną wolnością w PRL-u, duże bezrobocie wśród rodzin, korupcja, liczne przykłady źle pojętej solidarności wewnątrz klasy politycznej, ostatecznie coraz częstszy brak nadziei na lepszą przyszłość - oto tylko niektóre wyzwania w całym wielkim katalogu wyzwań społecznych, na które nie można pozostać dziś głuchym ${ }^{15}$. Koncentrując się na sprawach nie z tego świata, nie wolno zapominać, że droga do wieczności przebiega jednak na tym świecie. W takiej sytuacji ograniczenie działalności do np. samego tylko podejmowania ewangelizacji, w znaczeniu głoszenia orędzia o Jezusie Chrystusie, może okazać się niewystarczające. Formacja oazowa - zdaniem niektórych - dając znakomite podstawy tożsamości chrześcijańskiej, pokazując w swoich założeniach, iż życie chrześcijanina nie zna podziału na sacrum i profanum, że każde jego działanie winno być przeniknięte duchem chrześcijańskim, jednocześnie za słabo przygotowywała do dawania odpowiedzi, jak w praktyce żyć po chrześcijańsku w owej sferze świeckiej, tradycyjnie rozumianej jako profanum. Pedagogia oazowa ,znakomicie uczyła, jak się odnaleźć w Kościele, za słabo podpowiadała jak się odnaleźć w świecie. A wychowywano przecież świeckich w większości katolików, którzy swoje zadania powinni dostrzegać nie tylko

${ }^{11}$ Por. J. Colomb, De quelques conditions doctrinales et spirituelles pour l'annonce de JesusChrist à l'homme d'aujourd'hui, Vérité et Vie 20 (1968), z. 577, s. 1-20.

12 Por. M. Majewski, Tożsamość katechezy integralnej..., s. 100-101.

${ }_{13}$ Por. J. Colomb, La service de l'Evangile, Paris 1967, s. XIII nn.

${ }^{14}$ Por. M. Majewski, Tożsamość katechezy integralnej..., s. 113.

15 Por. Z. Nosowski, Oto czynię wszystko nowe..., s. 60. 
wewnątrz Kościoła, lecz jako członkowie Kościoła powinni być obecni w życiu społeczności ludzkiej"16.

Dlatego tak cenne są, podejmowane coraz częściej w Ruchu Światło-Życie inicjatywy w takich dziedzinach życia społecznego, jak: alkoholizm, homoseksualizm, przemoc w rodzinie, obrona życia, naturalne planowanie rodziny. Być może warto byłoby na nowo przemyśleć niektóre formy i metody programu rekolekcyjnego oazy, jak choćby tzw. wyprawę otwartych oczu, czy spotkania z tzw. „żywym Kościołem” na ONŻ III st., by wszystkie treści tam realizowane owocowały w pracy formacyjnej w ciagu roku konkretnym zaangażowaniem, które byłoby odpowiedzią na potrzeby i wyzwania współczesności. Ojciec Święty, Jan Paweł II, w Liście apostolskim Novo millennio ineunte, zwracając uwagę na owe współczesne wyzwania, jakie stoją przed Kościołem, mówi na przykład o potrzebie podejmowania konkretnych dzieł miłosierdzia na rzecz ubogich (np. wolontariat), dzieł związanych z poszanowaniem ludzkiego życia, potrzebie zaangażowania w dialog z ludźmi innego wyznania, czy innej kultury (por. NMI 48-51).

Pewna jednostronność wizji nauczania i wychowania religijnego, jaką przyniosła z sobą kerygmatyczna odnowa katechezy, koncentracja na treści przekazu, prowadząca nierzadko do „nie zauważania” przemian mentalności współczesnego człowieka, szczególnie młodzieży, sprawiała, iż coraz częściej okazywało się, że treść przekazu religijnego, mimo iż oparta na podstawowym źródle, jakim jest Pismo Święte, rozmijała się z zapotrzebowaniem młodego człowieka. Zaczęto stawiać sobie pytania, czy treść nauczania religijnego „nadąża” za zachodzącymi w szybkim tempie przemianami w mentalności współczesnego człowieka? I czy owa treść sytuuje się w kontekście człowieka i jego problemów, czy też może jest zupełnie obca jego doświadczeniu? ${ }^{17}$. Czy mentalność współczesnego człowieka, nastawionego raczej na rzeczywistość doczesną niż nadprzyrodzoną, jest w stanie przyjąć i zrozumieć takie treści, podawane w języku biblijno-teologicznym? Język ten, mający niewiele wspólnego z językiem, którym katechizowani posługują się na co dzień, wcale nie przybliżał im treści orędzia biblijnego, ale jeszcze bardziej prowadził do kontestacji mentorskiej metody katechetycznej, który wydawała się katechizowanym narzucaniem jakiegoś modelu wiary, który oni w bierny sposób, bez możliwości współudziału, powinni przyjąć. Toteż wcześniej czy później musiał pojawić się postulat dotyczący języka nauczania religijnego, w którym nie chodziło, aby zrezygnować z Biblii, ale aby Objawienie, naukę Kościoła, naukę o sakramentach, formułować ciągle na nowo i współczesnym językiem ${ }^{18}$. Dedukcyjny model nauczania nie przynosił już oczekiwanych skut-

${ }^{16}$ Por. Tamże, s. 61.

${ }^{17}$ Por. J. Bagrowicz, dz. cyt., s. 277-278.

${ }^{18}$ Por. B. Dreher, Die religiöse Situation der heutigen Jugend, Katechese im Zeichen christlicher Weltoffenheit, hrsg. E. Feifel, Augsburg 1968, s. 79-95. 
ków, katechizowani zaś, uwrażliwieni na uszanowanie ich wolności i na dialog, domagali się, aby w rzeczywistość religijną wprowadzać ich poprzez odwołanie się do ich codzienności, lub do sytuacji współczesnego człowieka czy świata.

Stąd, wydaje się słuszna, podjęta już w Ruchu, nowa redakcja niektórych podręczników oazowych i opracowywanie nowych (np. dla powstałej nowej formy oazy rekolekcyjnej: Oazy Nowej Drogi ${ }^{19}$ ), tworzenie nowych ośrodków wychowawczych, podejmujących działalność pastoralną i pedagogiczna, wspierająca szczególnie wszystkich odpowiedzialnych za nauczanie i wychowanie chrześcijańskie w Kościele (np. Ośrodek Profilaktyczno-Szkoleniowy im. ks. F. Blachnickiego w Katowicach ${ }^{20}$, czy Ośrodek „Odwaga”, działający przy ośrodku Ruchu Światło-Życie w Lublinie, proponujący pomoc duchową i terapeutyczną osobom o orientacji homoseksualnej), czy wreszcie próba korelacji programu formacyjnego Domowego Kościoła z programem całego Ruchu ${ }^{21}$.

Ciaggle jednak, mimo wielu podejmowanych dzisiaj prób dostosowywania języka nauczania i wychowania religijnego do potrzeb nowej mentalności, istnieje duży problem zrozumienia przez katechizowanych języka nauczania religijnego oraz przyjmowania przez nich pewnych treści i pojęć. Stąd, wydaje się iż jednym z najważniejszych elementów przekazu wiary jest dziś wpisanie jej w sytuację kulturowa, podjęcie przez Kościół dyskursu ze współczesną kultura, tego, co w ewangelizacji Kościoła nazywa się tzw. inkulturacja czy akulturacja wiary (por. DOK 109-110; 203-207; NMI 40) ${ }^{22}$.

$$
*
$$

Także w tym aspekcie, przed wspólnotami Ruchu Światło-Życie stoi ważne wyzwanie, aby - wykorzystując otwartość współczesnego człowieka na wartości

${ }^{19}$ Po wprowadzeniu do szkół podstawowych klas gimnazjalnych, w Ruchu Światło-Życie stworzona została trójstopniowa forma rekolekcji Oazy Nowej Drogi, odpowiadająca trzyletniej nauce $\mathrm{w}$ gimnazjum.

${ }^{20}$ Prowadzący różnego rodzaju warsztaty, spotkania, rekolekcje dla nauczycieli, katechetów, rodziców, wychowawców, animatorów. Spotkania te dotyczą różnych dziedzin życia duchowego, społecznego, np. problemu alkoholizmu w rodzinie, komunikacji interpersonalnej, umiejętności rodzicielskich, komunikacji małżeńskiej, pedagogiki zabawy, metod aktywizujących w katechezie, metod pracy z Pismem Świętym...

${ }^{21}$ Pragnienie to wypowiedział podczas XXVII Kongregacji Odpowiedzialnych Ruchu Światło-Życie, jego moderator generalny, ks. R. Litwińczuk: „Wreszcie - chyba mam prawo wypowiedzieć swoje marzenie - aby czymś naturalnym było, że dzieci rodzin z Domowego Kościoła wchodzą w formację Oazy dzieci Bożych i oazę młodzieżową, a potem znowu stają się Domowym Kościołem. Aby czymś naturalnym było, że młodzi ludzie zawierający związek małżeński, wywodzący się z formacji oazowej, nasi animatorzy - wchodzą w kręgi Domowego Kościoła. Permanentny deuterokatechumenat". R. Litwińczuk, Stowo programowe moderatora generalnego Ruchu Światto-Życie, w: Deuterokatechumenat. Referaty, s. 90.

${ }^{22}$ Por. J. Bagrowicz, Kontekst społeczno-kulturowy i eklezjalny współczesnego wychowania religijnego, Paedagogia Christiana 1 (9) 2002, s. 60-62; zob. A. A. Szubartowska, Kulturowy wymiar katechezy, Lublin 1997. 
nadprzyrodzone, a nawet narastający w nim duchowy głód ${ }^{23}$ - szukać sposobów takiej prezentacji duchowości chrześcijańskiej, która byłaby odpowiedzią na ich problemy i potrzeby, i pokazywałaby, iż dobro jest o wiele bardziej atrakcyjne niż $z^{24}$. Być może trzeba byłoby na nowo odczytać sens metafory oazy i pustyni. Oaza na pustyni ma znaczenie tylko wtedy, gdy niesie wszystkim wędrowcom nadzieję, że można gdzieś znaleźć źródło wody. Służyć ma ona wszystkim, którzy znajdą się na pustyni, a nie tylko tym, którzy gromadzą się przy niej na stałe ${ }^{25}$. Członkowie Ruchu Światło-Życie (ani żadnego innego ruchu, czy innej grupy religijnej) nie mogą być tylko zewnętrznymi obserwatorami świata, nie wchodzącymi w niego, tylko go krytykującymi. Jako ci, którzy już żyją w „oazie” i czerpią życie z jej źródła, winni wychodzić na pustynię w poszukiwaniu innych wędrowców umierających z pragnienia, i przyprowadzać ich w celu pokrzepienia i zaproszenia do skosztowania „wody żywej”.

Wydaje się, iż jest to jeden z ważniejszych współczesnych problemów edukacyjnych, domagający się w nauczaniu i wychowaniu religijnym otwarcia na człowieka i jego problemy, otwarcia na wartości humanistyczne. „Promocja i odkrycie wszystkich wymiarów człowieka jest łaską naszego czasu" ${ }^{26}$. Zadaniem chrześcijańskiego wychowawcy winno być, w takim ujęciu, takie kształtowanie wychowanków, aby umieli być chrześcijanami w świecie ciągle się zmieniającym. Nie musi to wcale oznaczać odejścia od kerygmatyki, ale jedynie pogłębione ,studium nad człowiekiem" 27 , otwarcie się nauczycieli religii i wychowawców na problemy, którymi żyje współczesny człowiek, szczególnie współczesna młodzież ${ }^{28}$.

W tym ujęciu, edukacja religijna powinna stawać się coraz bardziej „rozumiejącą", otwartą na dialog i współpracę z wychowankami. Osiaganie celu

${ }^{23}$ Ów duchowy głód można dostrzec szczególnie u młodzieży. Przejawia się on często w zbyt częstych i szybkich zmianach obiektu swych wierzeń. Raz są to utopie społeczne w postaci faszyzmu, hitleryzmu czy komunizmu, innym razem utopie psychologiczno - ezoteryczne, a nierzadko zdarza się też, że deifikują rasę, klasę, seks, pieniądze i cokolwiek...Odchodząc od wiary w jednego Boga, wkraczają w „politeizm”, tyle że nie zrytualizowany, często nie uświadomiony, podany w świeckiej oprawie. Por. F. Adamski, Człowiek współczesny wobec Transcendencji, Paedagogia Christiana 2 (8) 2001, s. 23-24.

${ }^{24}$ Problematyce, jak reklamować dobro i przekonująco pokazywać, że jego przyciągająca siła jest mocniejsza od uwodzicielskiej siły zła, poświęcony był cały numer „Więzi” z lipca 1997 r., noszący tytuł: Jak reklamować dobro?

${ }^{25}$ Por. Z. Nosowski, Oto czynie wszystko nowe..., s. 53.

${ }^{26}$ P. Babin, Options pour une education de la foi des jeunes, Lyon 1965, s. 31.

${ }^{27}$ M. Majewski, Katecheza młodzieży okresu dorastania, AK 91 (1978), s. 431-432.

${ }^{28}$ Sługa Boży sprzeciwiał się wyprowadzaniu koncepcji nauczania i wychowania w Kościele z samych tylko warunków społeczno-kulturowych. Nie ignorował ich jednak. Postęp katechetyczny rozumiał jako rozwój wynikający z otwartości katechezy na działanie Ducha Świętego, głównie realizującego misję Chrystusa w Kościele różnych czasów i środowisk. Por. M. Majewski, Koncepcja katechezy w ujęciu ks. dra hab. Franciszka Blachnickiego, w: Gorliwy apostoł wewnętrznej odnowy czlowieka..., s. 24. 
wychowania w katechezie, nie da się zrealizować bez stworzenia możliwości dialogu i dyskusji. Ponieważ katechizowani, pochodzą często ze środowisk zlaicyzowanych i nie są przygotowani do przyjęcia orędzia Ewangelii, potrzeba, aby w realizacji celu wychowania religijnego, którym jest wychowanie do dojrzałości w wierze, wychowawca uwzględniał wpierw naturalne dobro człowieka, jego życiową sytuację, doświadczenie religijne, poszukiwania i niepokoje ${ }^{29}$. Ks. J. Bagrowicz mówi w tym kontekście o takim etapie w wychowaniu, który nazywa „uwolnieniem” w uczniach ich własnego słowa. Wychowankowie powinni czuć, że daje im się możliwość wypowiedzenia swojej sytuacji życiowej, swojego zagubienia, swojej często niewiary. Powinni czuć, że mogą wypowiadać to, co noszą w sobie najgłębiej bez żadnych obaw, w atmosferze wolności. Dopiero wtedy wychowawca może poznać swoich podopiecznych i sam staje się dla nich , kimś”. I dopiero wtedy możliwe jest przejście od rozważania sytuacji życiowych wychowanków do ukazania im w pełni perspektywy ich rozwoju przez spotkanie ze Słowem Bożym. Taką pedagogię zastosował Jezus w spotkaniu z Samarytanką (por. J 4, 1-42). „Uwalniając” w niej jej własne słowo, prowadził ją do odkrywania prawdy o samej sobie, a wreszcie przeszedł do odkrywania wiecznego wymiaru jej życia ${ }^{30}$. „Studnia Jakubowa” z owej przypowieści staje się symbolicznie przestrzenią wolności, miejscem, w którym można znaleźć atmosferę swobodnej wymiany wypowiedzi i wymiany myśli, które w ten sposób staje się przygotowaniem do przyjęcia Dobrej Nowiny. Można tu mówić o pedagogice prekatechezy, a więc o takim etapie nauczania i wychowania, na którym wychowankowie dojrzewają - w stworzonym przez wychowawcę klimacie wolności i tolerancji - do spotkania ze Słowem Bożym ${ }^{31}$.

Można odnieść wrażenie, że właśnie ten moment w pedagogii Ruchu Światło-Życie, jak zresztą i w wielu innych ruchach i grupach religijnych, domaga się głębszej refleksji pedagogiczno-katechetycznej i rozpoznania w nim jednego z kluczowych momentów w realizacji celu wychowawczego, jakim jest wychowanie do dojrzałości w wierze. O ile coraz więcej członków Ruchu podejmuje $\mathrm{z}$ większą świadomością swoją formację deuterokatechumenalna, o tyle istnieje ciagle jeszcze spora grupa tych, którzy przychodzą „do oazy”, odchodzą prędko, nie umiejąc w niej odkryć dla siebie miejsca i nie znajdując tam możliwości rozwiązywania swoich życiowych dylematów. Zbyt szybkie przejście do przedstawiania im warunków, jakie wynikają z ich obecności w oazie (np. co tygodniowe spotkania, praca z notatnikiem), albo zbyt szybkie przejście do głoszenia kerygmatu „ochrzczonemu poganinowi”, decyduje często o niechęci do wejścia w taką społeczność. Współczesny młody człowiek, mimo iż wyraża chęć nawrócenia i odnowienia swojej wiary, często jeszcze przez długi okres czasu nie jest w stanie zostawić starego świata, i nie wyobraża sobie, aby ten nowy mógł dać mu to,

\footnotetext{
${ }^{29}$ Por. K. Olbrycht, Dylematy wspótczesnego wychowania, Znak 3 (1991), nr 9, s. 44-45.

${ }^{30}$ Por. J. Bagrowicz, Katecheza jako wychowanie, Horyzonty Wiary 7 (1996), nr 3, s. 46-48.

${ }^{31}$ Por. Tamże, s. 47.
} 
co otrzymuje aktualnie, żyjąc z daleka od Boga. Wejście do jakiejkolwiek grupy religijnej kojarzy mu się zwykle z ograniczeniem dostępu do tego, co do tej pory stanowiło źródło jego radości i przyjemności. Stąd, błędem byłoby narzucanie mu jakiegoś modelu wiary z góry, bez jego współudziału, i bez możliwości dokonywania wyboru. Toteż, wydaje się, iż właśnie pedagogika prekatechezy, a może bardziej pedagogika prekatechumenatu powinna stać się przedmiotem głębokiego namysłu pastoralistów, katechetów i wychowawców, zarówno prowadzących katechezę na lekcji religii, jak i podczas spotkań formacyjnych w różnych wspólnotach parafialnych, ruchach czy grupach religijnych.

„Studnia Jakubowa” nie ma nigdzie większej racji bytu niż właśnie w „oazie”. I aby uczynić „wodę żywą” (osobę Jezusa Chrystusa) bardziej cenną i ,atrakcyjną", trzeba zaprosić wszystkich spragnionych do spotkania przy studni, podczas którego, zanim rozpocznie się ewangelizacyjne: „o gdybyś znała dar Boży”(por. J 4, 10), zacznie się zwykłą, może nawet prowokującą rozmowę, typu: ,ty daj mi pić" (por. J 4, 7). Pojawia się wtedy szansa dialogu nie tylko z tymi, którzy już wierzą, ale także z tymi, którzy wierzą bardzo słabo i którzy nie wierzą w ogóle, a nawet z tymi, którzy otwarcie kwestionują wiarę w Jezusa Chrystusa i oddają często swój umysł i emocje na wpływy niebezpiecznych sekt i pseudoreligijnych grup. Chodziłoby więc o stworzenie takiego miejsca w oazie, gdzie w klimacie wolności i poczucia bezpieczeństwa mogłyby spotkać się ze sobą „rzeczywistość wyobcowania życia codziennego z motywacji religijnej, z rzeczywistością religii wyobcowanej z problematyki codzienności”.

Taką rzeczywistość spotkania, podczas którego - w atmosferze wzajemnej wolności i zaufania - następuje dialog wychowanka z wychowawcą, ks. J. Tarnowski nazywa „współ-myśleniem”. Przy czym udział wychowawcy w tym dialogu wyznaczony jest przez trzy imperatywy: słuchać! pytać! niepokoić! ${ }^{32}$ Spotkanie takie nie jest wówczas wtłaczaniem wychowanka w przygotowane formuły religijne, ale staje się wspólnym dochodzeniem do prawdy, „współ-myśleniem”, „współ-poszukiwaniem” i powiedzielibyśmy: „współ-przygotowaniem” do aktu i postawy wiary.

Bez stwarzania takich możliwości „współ-myślenia”- na katechezie, w grupach religijnych - formacja może kończyć się całkowitym fiaskiem lub pozostawać na poziomie budowania jedynie elitarnych enklaw religijności. Dotyczy to przede wszystkim formacji w ruchach i stowarzyszeniach religijnych, w tym także Ruchu Światło-Życie. Wielu z nich, realizując hasło, które także ks. F. Blach-

${ }^{32}$ Por. J. Tarnowski, Wspót-myślenie wychowaniem do wiary, Paedagogia Christiana 2 (8) 2001, s. 35-51; zob. J. Tarnowski oraz Dziecięcy Zespół Redakcyjny, Ryby i dzieci głosu nie maja? Twój głos o Bogu, religii i duchach, Warszawa 1991; tenże, Twój głos o rodzinie, marzeniach i nie tylko, Warszawa 1991; tenże, Twój głos o szkole, uczniach i nauczycielach, Warszawa 1993; tenże, Twój głos o koleżeństwie, przyjaźni i miłości, Toruń 1996; tenże, Twój głos o przyrodzie, zwierzętach $i$ środowisku, Warszawa 1998. 
Pedagogia Ruchu Światło-Życie propozycją „,na dzisiejszą godzinę Kościoła” 91

nicki promował, tworząc Ruch Światło-Życie: „elity w służbie mas”, udawało się realizować jedynie pierwszą część owego hasła, zapominając, iż elitarne wspólnoty mają o tyle sens, o ile - na podobieństwo drożdży w cieście - stają się zaczynem pogłębiania wiary pośród całej społeczności religijnej. Mimo raczej negatywnych skojarzeń związanych z masowością polskiego katolicyzmu, to jak zauważa Z. Nosowski - masowość ta jest wartością też cenną, i jednym z najważniejszych wyzwań dla współczesnego Kościoła powinno być, jego zdaniem, dążenie do połączenia masowości z duchową głębią. Katolicyzm w Polsce jest ciaggle oczywistością kulturową i jest to wielki kapitał, którego nie można zmarnować. Elitarne wspólnoty o tyle mają rację istnienia, o ile stają się narzędziem do pogłębiania polskiej religijności ${ }^{33}$.

Gotowość do przyjęcia takiego wezwania przez Ruch Światło-Życie wyraził podczas XXVII Kongregacji odpowiedzialnych Ruchu Światło-Życie, moderator generalny, ks. R. Litwińczuk:

Z Ewangelią Jezusa nie można zamknąć się w czterech ścianach, przy świeczce, gdzie dobrze się czujemy, gdzie jest bezpiecznie. Trzeba wychodzić do świata, nie obrażać się na świat. Trzeba iść do tego, co stanowi centrum tego świata, jak ówczesnym centrum świata był Rzym. Wcielenie Chrystusa przekonuje nas, że świat Boży i każdy człowiek jest Boży, choćby był grzesznikiem. Apostołowie mieli odwagę. Poznali Jezusa, Jego moc, moc Jego Ewangelii i dla takich niestraszny już był Rzym Cezara, siedlisko zła. Trzeba nam rozpoznać Jego oblicze i spieszyć do braci, aby nieść im wspaniałą nowinę: Widzieliśmy Pana!"34.

Widać więc, iż w sytuacji, gdy religijność ludzi staje się coraz bardziej selektywna, z osłabionymi więzami z lokalną wspólnotą wyznaniową, gdy z drugiej strony pojawiają się w niej nurty fundamentalne, radykalne, nierzadko w postaci sekt i wattpliwej wartości grup religijnych, zagadnienie edukacji religijnej nabiera szczególnego znaczenia. Zasadniczym problemem staje się odpowiedzialne ustawienie relacji pomiędzy zmieniającą się świadomością religijną człowieka współczesnego a konfesyjnym charakterem zajęć. Przed odpowiedzialnymi za nauczanie i wychowanie religijne stoi zadanie opracowania modelu edukacji religijnej, rzetelnego teologicznie i pedagogicznie, a zarazem uwzględniającego określony kontekst dydaktyczny, społeczny i kulturowy ${ }^{35}$. V. Drehsen wskazuje, iż Kościół katolicki, korzystając między innymi z doświadczeń ewangelickich, powinien nauczyć się trzech brakujących, a potrzebnych rzeczy: ,integracji wiary z życiem”, „otwartego charakteru wiary” i „otwarcia na Transcendencje”,

${ }^{33}$ Por. Z. Nosowski, Oto czynię wszystko nowe..., s. 52.

${ }^{34}$ Por. R. Litwińczuk, Stowo programowe moderatora generalnego Ruchu Światto-Życie..., s. 91.

${ }^{35}$ Por. B. Milerski, Religijność młodzieży współczesnej, Paedagogia Christiana 1 (5) 2000, s. 115.

${ }^{36}$ Por. V. Drehsen, Alles andere als Nullbock auf Religion. Religiöse Einstellungen zwischen Wahlzwang und Fundamentalismus, Jahrbuch der Religionspädagogik (JRP) 19 (1995), s. 47-69. 
Ten sam autor podkreśla, że zamiast dziś szukać odpowiedzi na pytanie: jaki obraz Kościoła powinni przekazywać dorośli młodzieży, powinno się raczej stawiać pytanie: w czym objawia się niedostępność i niedoskonałość Kościoła, którą krytykuje coraz więcej młodych, a z nimi także bardziej dystansujących się od Kościoła dorosłych. Religijność młodzieży może służyć jako wskaźnik braków religijności dorosłych ${ }^{37}$. Analogicznie, skuteczność wszelkich działań wychowawczych czy to na katechezie, czy to w małej grupie wspólnoty parafialnej, może być wskaźnikiem braku znajomości mentalności współczesnego człowieka, oraz brakiem wyżej wymienionych: integracji wiary z życiem, otwartego charakteru wiary i otwarcia na rzeczywistość nadprzyrodzona.

Ksiądz bp W. Skworc, były asystent kościelny Ruchu Światło-Życie z ramienia Episkopatu Polski, podczas Mszy świętej, celebrowanej dla odpowiedzialnych Ruchu Światło-Życie w dniu 2 marca 2002 r. na Jasnej Górze, stawiał liderom wspólnot oazowych pytania:

czy wy - tworzący Ruch Światło-Życie, tu obecni i nieobecni - jesteście na tyle silni i przekonywający jako eklezjalna wspólnota, by innych prowadzić do Chrystusa?! Czy może zajęci auto-organizacją, czy też rzeczywistymi, a może nieraz urojonymi problemami, dostrzegacie konieczność prowadzenia dzieła deuterokatechumenatu, mającego na celu przybliżenie innym osoby Jezusa Chrystusa?! Czy macie dość siły duchowej, aby wspólnoty Ruchu Światło-Życie stawały się miejscem doświadczenia Jezusa historycznego, co jest istotą katechumenatu? Czy jesteście naprawdę obecni w Kościele, a Kościół w was?! ${ }^{38}$

Te fundamentalne pytania stają się na początku nowego tysiąclecia kolejnym wyzwaniem dla Ruchu Światło-Życie, dla jego odpowiedzialnych, dla tych, którzy są wezwani, aby kontynuować ideę, „Żywego Kościoła” ks. F. Blachnickiego. Wydaje się, że ich wierność Słudze Bożemu, powinna polegać dzisiaj na bardziej wnikliwym rozpoznawaniu znaków czasu i realizowaniu w „tu i teraz” Kościoła, drogą deuterokatechumenalną, charyzmatu ,światło-życie”, nie zapominając, do jakiego typu człowieka zwraca się ze swoim ideałem wychowawczym: czy człowiek ów jest w stanie wejść od razu na drogę wiary, czy też może potrzebuje wpierw „oazy” jako środowiska umożliwiającego mu wypowiedzenie swoich życiowych dylematów i niepokojów, a następnie dopiero wejście w dialog - „współ-

Zob. H. A. Zwergel, Potrzeba tożsamości i sensu w (post) modernistycznym świecie-wyzwanie dla szkolnej lekcji religii, Paedagogia Christiana 2 (8) 2001, s. 17.

${ }^{37}$ Por. V. Drehsen, Alles andere als Nullbock auf Religion. Religiöse Einstellungen zwischen Wahlzwang und Fundamentalismus..., s. 58-60.

${ }^{38}$ W. Skworc, Homilia wygtoszona podczas Eucharystii w sobote, 2 marca 2002 r.w czasie trwania XXVII Kongregacji Odpowiedzialnych Ruchu Światto-Życie w Częstochowie, na Jasnej Górze, w: Deuterokatechumenat. Referaty. Dyskusja panelowa. Stowo programowe. Homilie. XXVII Kongregacja Odpowiedzialnych Ruchu Światto-Życie, Częstochowa-Jasna Góra 1-4 marca 2002 r., Katowice 2002, s. 99. 
Pedagogia Ruchu Światło-Życie propozycją „na dzisiejszą godzinę Kościoła” 93

myślenie" z tymi, którzy, w trakcie owego dialogu - ukażą mu możliwość rozwiązania owych problemów i rozpoznania swych życiowych zadań i wyzwań na płaszczyźnie spotkania z Bogiem. Wymaga to rewizji tych wszystkich elementów programu formacji oazowej, by nie rezygnując z żadnego, odczytać na nowo te, w których Ruch Światło-Życie mógłby szczególnie realizować ów jeden z podstawowych wymiarów diakonii Kościoła wobec współczesnego człowieka, tj. pomóc mu w rozpoznaniu jego życiowych zadań i wyzwań poprzez stworzenie mu przestrzeni wolności najpierw w wymiarze ludzkiego spotkania.

Otwarcie się w nauczaniu i w wychowaniu religijnym na człowieka i jego problemy nie oznacza tu wcale odejścia od kerygmatyki i zerwania z Objawieniem i nauczaniem Kościoła. Przedstawiciele tzw. nurtu tematyczno-problemowego $^{39}$ ewangelickiej pedagogiki religijnej twierdzą, iż zadaniem wychowania chrześcijańskiego nie jest w pierwszym rzędzie przekaz doktrynalnych prawd i zapamiętanie ich przez uczniów, ale

egzystencjalne doświadczenie, iż religia jest jedną z możliwości życia. Być może tą właściwą?...Edukacja religijna powinna ukazać, że religia może stanowić realną odpowiedź na wiele pytań człowieka żyjącego we współczesnym świecie. Aby osiagnąć powyższy cel, należy rozpocząć nauczanie nie od prawd wiecznych, ale od tematów związanych z doczesnością. Tematy te należy jednocześnie zaprezentować jako rzeczywiste problemy, których przezwyciężeniu poświęcone jest kształcenie. Tak ujęte nauczanie jest realizowane w nadziei, że w trakcie procesu dydaktycznego zostanie zapośredniczona prawdziwa wiara, będąca wynikiem spotkania człowieka z Bogiem ${ }^{40}$.

Ów służebny (diakonijny) wymiar współczesnej edukacji religijnej, polegający na otwarciu się na człowieka i jego problemy, nie musi wcale prowadzić do zerwania z jej konfesyjnym charakterem, lecz może pomóc w odczytywaniu źródeł chrześcijańskiej wizji wychowania w sposób, który jest bliższy współczesnemu człowiekowi ${ }^{41}$. Siłą formacji deuterokatechumenalnej wydaje się jej

${ }^{39}$ Zdaniem pedagogów i teologów ewangelickich zarówno teoria, jak i praktyka wychowania, powinny zostać usytuowane w perspektywie rzeczywistych pytań i tematów człowieka współczesnego. Przemiany społeczne w świecie, a szczególnie pluralizacja i indywidualizacja życia, wpływają na przemiany religijności i domagają się jednocześnie modyfikacji koncepcji edukacji religijnej. W procesie wychowawczym należałoby więc uwzględniać konkretny kontekst życiowy ucznia (postulat kontekstualizacji) oraz bazować na jego elementarnych doświadczeniach (postulat elementaryzacji). Powyższe przesłanki doprowadziły do ukonstytuowania się nowego nurtu ewangelickiej pedagogiki religii, a mianowicie tematycznego, bądź tematyczno-problemowego. Por. Por. B. Milerski, Nurty w ewangelickiej pedagogice religii XX wieku, Paedagogia Christiana 2 (8) 2001, s. 68-70; zob. K. E. Nipkow, Grundfragen der Religionspädagogik, t. 1-3, Gütersloh 1975-1982;

${ }^{40}$ B. Milerski, Nurty w ewangelickiej pedagogice religii XX wieku, Paedagogia Christiana 2 (8) 2001, s. 70; zob. H. Schmidt, Leitfaden Religionspädagogik, Stuttgart 1991, s. 39nn.

${ }^{41}$ Por. J. Bagrowicz, Edukacja religijna wspótczesnej młodzieży..., s. 284-289. 
teocentryczne i chrystocentryczne ukierunkowanie oraz eklezjocentryczny wymiar nauczania i wychowania religijnego, zarówno w jej teoretycznych założeniach, jak i w realizacji praktycznej. Wydaje się, że wzbogacenie tego ideału wychowawczego o pogłębienie w nim owego „diakonijnego" wymiaru wobec współczesnego człowieka - oznaczającego wnikliwe studium jego mentalności, poznanie jego potrzeb, lęków i niepokojów, o porozumiewanie się z nim poprzez kulturę (literaturę, muzykę, sztukę), a także rozszerzenie posługi nauczania i wychowania religijnego o znajomość i przekaz - już nie tylko określonej wiedzy teologicznej - ale także podstawowych kompetencji z zakresu nauk o człowieku oraz współczesnych nauk o wychowaniu ${ }^{42}$ - mogłoby pomóc w obecnych czasach w odczytywaniu na nowo, z tak wspaniale wypracowanej przez ks. F. Blachnickiego pedagogii, źródeł chrześcijańskiej wizji wychowania „na dzisiejszą godzinę" Kościoła.

\section{Erzieherische Tätigkeit der Bewegung „Licht und Leben” ein Vorschlag für heutige Stunde der Kirche (Zusammenfassung)}

Vor 30 Jahren hat der Priester Franciszek Blachnicki eine Frage nach Katechumenat „für heutige Stunde” der Kirche gestellt. Katechumenat, das eine fruchtbare Realisierung des Prozesses, wie man Christ wird, ermöglicht und zum reifen Glauben im Rahmen jeder Lokalgemeinschaft in der Kirche und in der Gemeinde führt. Im Zusammenhang mit dieser Frage ist ein neuer Blick auf erzieherische Tätigkeit der Bewegung „Licht und Leben" und ihre Aufgaben beachtenswert.

Die Tätigkeit des Priesters Franciszek Blachnicki war ein ständiges Ablesen der Zeichen der Zeit und ihre praktische Anwendung. Indem er sich in die Dokumente des II. Vatikanischen Konzils einlas, die Geschichte und ihm gegenwärtige Ereignisse beobachtete, schuf er „laufend” neue Seelsorgerformen. Diese rief er ab sofort ins Programm der Gemeinschaften der Bewegung „Licht und Leben” und dadurch ins Leben der Gemeinde. Heutzutage entsteht eine Grundaufgabe für die Bewegung „Licht und Leben” und nämlich aktuelles Ablesen der Pastoralintuition des Gründers und die Beantwortung der Frage, ob das Bilden in der Bewegung den neuen Bedürfnissen angepasst wird.

${ }^{42}$ Chodzi o to, aby w sposób całościowy i realistyczny rozumieć wychowanka i pomagać mu w kształtowaniu chrześcijańskiej dojrzałości we wszystkich sferach ludzkiego życia. Jednym z największych zagrożeń - jak twierdzi M. Dziewiecki - w formacji współczesnych wychowawców religijnych, animatorów wspólnot katolickich, katechetów, jest z jednej strony brak odpowiedniego przygotowania antropologicznego i psychopedagogicznego, a z drugiej strony bezkrytyczne korzystanie z postulatów wychowawczych zawartych w modnych obecnie systemach psychopedagogicznych, które oparte są na zubożonej antropologii oraz na powierzchownej wizji relacji międzyludzkich, zredukowanych do indywidualizmu i subiektywizmu. Por. M. Dziewiecki, Psychopedagogiczna formacja katechetów w obliczu nowej ewangelizacji, w: Ewangelizować czy katechizować?, red. S. Dziekoński, Warszawa 2002, s. 187. 
Die erzieherische Konzeption der Bewegung „Licht und Leben”, die mit dem kerygmatischen Lehren und religiöser Erziehung im Zusammenhang steht, sich auf überirdische Gründe stützt, die Wirklichkeit des Gottes Wortes und der Liturgie ergründet, erwies sich Ende der 60-er und 70-er Jahre des XX Jahrhunderts als unzulänglich. Die Säkularisierungs- und Dechristianisierungsprozesse hatten einen großen Einfluß auf das Leben der Kirche, auf den Inhalt und die Methode der Erziehungswirkung und auf das Religionslehren. Erzieherische Tätigkeit in der Bewegung „Licht und Leben” mußte (und muss immer noch) mit dem kommenden geselschaftlichen und kulturellen Wandel in Polen konfrontiert werden. Mit dem Wandel, der mit den Jugendlichen, ihren Problemen und ihrer Sprache in Verbindung steht. Es wird hier die Sprache gemeint, die näher der wachsenden Jugendmentalität steht.

Vor den Gemeinschaften der Bewegung „Licht und Leben” steht eine ernste Herausforderung, die Offenherzigkeit für die überirdischen Werte des Gegenwartsmenschen und den wachsenden geistigen Hunger auszunutzen. Sie sollten auch nach. Art und Weise der Präsentation der Christengeistigkeit suchen, die eine Antwort auf ihre Problemeund Bedürfnisse ist. Sie sollte auch zeigen, dass das Gute attraktiver als das Übel ist. Es musste kein Abgang von der Kerygmatik bedeuten, es geht um „Studium an den Menschen”, d.h. die Offenherzigkeit für Probleme,die den Gegenwartsmenschen betreffen, besonders Gegenwartsjugendliche.

In diesem Zusammenhang sollte erzieherische Tätigkeit der Bewegung „Licht und Leben” immer mehr ,verstehender”, offener für den Dialog und die Mitarbeit mit den Zöglingen werden. Es ist notwendig, Gewicht auf das Lehren und die Erziehung zu legen. Auf diese Lebensabschnitte, die mit dem Reifen der Zöglinge aufs Treffen mit Gottes Wort verbunden sind, in der Atmosphäre der Freiheit und Toleranz, die von den Erzieher geschafft wurde. Solche erzieherische Tätigkeit, die man als Pädagogie des Prekatechumenats genannt werden kann, hat Jesus im Treffen mit der samaritischen Frau in Anwendung gebracht (J.4,1-42). ,Jakobs Brunnen” aus jener Parabel wird zum Symbol der Freiheit, „eine Oase”, ein Ort, an dem eine freundliche Atmosphäre der Äußerung und des Gedankenaustausches gefunden wird. Ein Ort, der auf diese Art und Weise eine Vorbereitung auf Nehmen Guter Nachricht wird.

Es scheint, dass Treue der erzieherischen Tätigkeit der Bewegung „Licht und Leben" den Ideen, die von dem Priester Fr. Blachnicki einprägt wurde, sollte heutzutage auf der Erkennung der Zeichen der Zeit und der Realisierung in ,jetzt und hier” der Kirche beruhen. Diese Realisierung sollte auf dem Weg des Deuterokatechumenats, im Charismat „Licht und Leben” durchgeführt, ohne den Menschen zu vergessen, an den man sich mit seinem Erziehungsideal wendet. Es bedarf der Überprüfung aller Elemente des Programms, ohne auf einen zu verzichten die anderen aufs neue abzulesen. Es geht um Hilfe dem Gegenwartsmenschen seine Lebensaufgaben zu erkennen.

Die Bereicherung dieses Erziehungsideals um Vertiefung der „diakonischen” Bedeutung dem Gegenwartsmenschen gegenüber, kann heutzutage behilflich sein, aufs neue abzulesen, aus der von Priester Fr. Blachnicki gearbeiteten erzieherischen Tätigkeit, die Quellen des christlichen Erziehungsbildes „für heutige Stunde” der Kirche. 